www.jmscr.igmpublication.org

Impact Factor (SJIF): 6.379

Index Copernicus Value: 71.58

ISSN (e)-2347-176x ISSN (p) 2455-0450

crossref DOI: _https://dx.doi.org/10.18535/jmscr/v6i2.112

Journal Of Medical Science And Clinical Research

IGM Publication

An Official Publication of IGM Publication

\title{
Post-Operative Analgesia in Children: A Comparison between Caudal Bupivacaine with Buprenorphine and Caudal Bupivacaine with Rectal Diclofenac
}

\author{
Authors \\ Dr Harsh Kumar Harsh ${ }^{1}$, Dr Anita Harsh ${ }^{2}$, Dr Prafful Kachhwaha ${ }^{3}$ \\ ${ }^{1}$ Senior Specialist, Department of Anaesthesiology, S.M.S. Medical College and Hospital, Jaipur \\ ${ }^{2}$ Associate Professor, Department of Pathology, S.M.S. Medical College, Jaipur \\ ${ }^{3}$ Ex. Professor, Dr. S.N. Medical College, Jodhpur \\ Corresponding Author
}

Dr Anita Harsh

Associate Professor, Department of Pathology, S.M.S. Medical College, Jaipur

Address: 241/3, Parwati Marg, Raja Park, Jaipur-302004 India

Email: drhkharsh@yahoo.com

\begin{abstract}
Background: Relief of post-operative pain is provided traditionally by single drug regimens but combinations of different regimens have been suggested to be more rational and effective. Rectal administration of NSAIDs in children is a safe and convenient route of drug absorption. The present study was designed to compare the efficacy and safety of caudal bupivacaine $(0.125 \%)$ either with buprenorphine $(4 \mu \mathrm{g} / \mathrm{ml})$ or with rectal diclofenac suppository $(2.5 \mathrm{mg} / \mathrm{kg})$.

Material \& Methods: The present study was carried out on 50 children in the Department of Anaesthesiology and critical care at the attached group of hospitals, Dr. S.N. Medical college, Jodhpur. The randomly selected children belonging to either sex were allocated to two groups, each group consisted of 25 children. Routine monitoring of every child included precordial stethoscope, ECG, NIBP, SpO2 through pulse oxymeter and temperature. After surgery the children were transferred to recovery ward and were observed up to 1 hour and then in post-operative ward at 1, 4, 6, 12, 24 hours.

Results: Our study showed that the mean age of patients in group A was $4.78 \pm 2.446$ yrs and group B was $5.240 \pm 2.521$ yrs, it was not statistically significant $(P>0.05)$ and mean values of weight and duration of surgery were also not statistically significant $(P>0.05$ respectively). At 6 hours of observation one patient in group A and 2 patients in group B demanded for rescue analgesia. At 12 hours of observation 4 patients from both groups demanded for rescue analgesia.

Conclusion: We concluded that caudal bupivacaine $0.125 \%$ in a dose of $1 \mathrm{ml} / \mathrm{kg}$ with rectal diclofenac $\mathrm{Na}$ suppository in a dose of $2.5 \mathrm{mg} / \mathrm{kg}$ just after induction of anaesthesia provides equivalent analgesia up to 24 hour in postoperative period with minimum side effects and lesser incidences of nausea and vomiting, sedation, time taken to void urine, in comparison to caudal bupivacaine in the same dose along with buprenorphine.
\end{abstract}

Keywords: Post-operative pain, Caudal anaesthesia, Buprenorphine, Bupivacaine, Rectal diclofenac Na. 


\section{Introduction}

The perception of pain in children is now no more a myth but a real fact and the detrimental effects associated with post-operative pain in the form of physical, physiological, social, emotional and psychological changes have been appreciated more authentically, so various routes, methods, drugs and technique have been adopted to minimize or alleviated post-operative pain.

Caudal anaesthesia has become increasingly wide spread in paediatric surgery in recent years especially for operations below the umbilicus as it is simple, safe and effective. Since the first paediatric report in $1933^{1}$, several studies have described the indication for paediatric caudal block, the level of analgesia, recommended doses and pharmacokinetics of local anaesthetics used in caudal anaesthesia, general or specific advantages and disadvantages of the technique.

Because of long duration of action, bupivacaine the local anaesthetic agent is used most commonly for caudal epidural blockade. A simple working rule is in children less than 6 months of age $1 \mathrm{ml} / \mathrm{kg}$ of bupivacaine $0.125 \%$ will block low thoracic dermatomes. In children above this age and below $20 \mathrm{~kg}$ wt $1 \mathrm{ml} / \mathrm{kg}$ of bupivacaine $0.25 \%$ will consistently block inguinal dermatomes, while above this weight the technique becomes inconsistent at blocking inguinal dermatomes. Pharmacokinetic data from several studies show that single epidural doses of $2.0-2.5 \mathrm{mg} / \mathrm{kg}$ of bupivacaine are associated with low plasma level of bupivacaine. However, few studies indicate that caudal block may results into more extensive block than is necessary. ${ }^{2}$ caudal block may relieve early post-operative pain, but in the later period systemic analgesia was shown to be superior.

Relief of post-operative pain is provided traditionally by single drug regimens but combinations of different regimens have been suggested to be more rational and effective. ${ }^{3}$ The argument for the use of a combination of analgesics is that drugs acting by different mechanisms results in additive or synergistic analgesia. $^{4}$ Opioids act on specific opioid receptors in the CNS to attenuate the pain related signals, while NSAIDS act mainly at the periphery to inhibit the initiation of pain signals interfering with prostaglandin synthesis after tissue injury.

Rectal administration of NSAIDs in children is a safe and convenient route of drug absorption and diclofenac is available commercially in a paediatric suppository formulation. Diclofenac is completely absorbed after rectal administration and the sustained action of the drug may provide analgesia in the early and late post-operative phases, whilst the respiratory depressant effects of conventional opioid analgesia are avoided.

Buprenorphine has five times greater lipid solubility than morphine. When given epidurally, it has a 50 times higher affinity for $\mu$ opioid receptors in the dorsal horn of the spinal cord than morphine ${ }^{5}$. This should also extend its duration of action and has been confirmed clinically ${ }^{6}$.

Caudal block using bupivacaine plus buprenorphine has reported as providing very effective, prolonged analgesia with few side effects in children after genitor-urinary surgery without any occurrence of late respiratory depression. $^{7}$ Several earlier clinical studies also reported a lack of late respiratory depression after epidural buprenorphine ${ }^{6,8}$, even in high doses ${ }^{9}$.

Since, the literature is silent and scarce on the issue of comparison of opiates and NSAIDS along with caudal bupivacaine, the present study was designed to compare the efficacy and safety of caudal bupivacaine $(0.125 \%)$ either with buprenorphine $(4 \mu \mathrm{g} / \mathrm{ml})$ or with rectal diclofenac suppository $(2.5 \mathrm{mg} / \mathrm{kg})$.

\section{Material \& Methods}

The present study was carried out on 50 children in the Department of Anaesthesiology and critical care at the attached group of hospitals, Dr. S.N. Medical College, Jodhpur.

The randomly selected children belonging to either sex were allocated to two groups, each group consisted of 25 children, as follow:- 
1. Group A (25 patients)- The children received caudal bupivacaine $0.125 \%$ and buprenorphine $4 \mu \mathrm{g} / \mathrm{ml}$ in a dose of $1 \mathrm{ml} / \mathrm{kg}$ upto a maximum of $30 \mathrm{ml}$, just after induction of general anaesthesia.

2. Group B (25 patients)- The children received caudal bupivacaine $0.125 \%$ in a dose of $1 \mathrm{ml} / \mathrm{kg}$ upto a maximum of $30 \mathrm{ml}$ and rectal diclofenac suppository in a dose of $2.5 \mathrm{mg} / \mathrm{kg}$ just after induction of general anaesthesia.

\section{Inclusion criteria}

1. Age, varied from 1-10 years.

2. The children presented for surgery such as herniotomy, orchidopexy and urethroplasty.

3. The children belonging to ASA grade II and I.

4. After getting approval from ethical committee.

5. After getting written and informed parent consent.

\section{Exclusion criteria:}

1. The children who had history of allergy or sensitivity to bupivacaine and diclofenac.

2. Any contraindication to caudal injection i.e. infection at the site, bleeding disorder, caudal vertebral anomalies etc.

Besides the complete examination of children, the either of parents was also interviewed to establish a close rapport with him or her and all the details of anaesthetic procedure and the technique to be adopted for post-operative pain relief with advantages and disadvantages associated with the technique were explained to them and a written and informed consent was taken.

Routine monitoring of every child included precordial stethoscope, ECG, NIBP, SpO2 through pulse oxymeter and temperature.
After surgery the children were transferred to recovery ward and were observed up to 1 hour and then in post-operative ward at 1, 4, 6, 12, 24 hours.

\section{Results}

Our study showed that the mean age of patients in group A was $4.78 \pm 2.446 \mathrm{yrs}$ and group B was $5.240 \pm 2.521 \mathrm{yrs}$, it was not statistically significant $(\mathrm{P}>0.05)$ and mean values of weight and duration of surgery were also not statistically significant ( $\mathrm{P}>0.05$ respectively) (table 1 ).

The mean values of pulse rate $\&$ respiratory rate pre-operatively were $103.2 \pm 5.03, \quad 18.20 \pm 1.71$ respectively in group A \& 102.96 $\pm 5.6,17.68 \pm 1.68$ respectively in group $\mathrm{B}$, but were not statistically significant and mean values of pulse rate \& respiratory rate slightly increased post-operatively in both groups but were not statistically significant ( $\mathrm{P}>0.05$ respectively) (table 2 ).

The pain scores were statistically comparable with no difference at all time of observation between two groups (table 3). Most of the children in group A were more drowsy (grade-2) as compared to group B. After 12 hours of observation degree of sedation between the two groups was found to be statistically significant $(\mathrm{P}<0.05)$ (table 4$)$.

Demeanour score was comparable between two groups during all the time of observation. The observation was statistically insignificant between two groups (table 5). After 6 hours of observation, all the children had full motor recovery and there was no statistical significant difference between the two groups (table 6).

At 6 hours of observation one patient in group A and 2 patients in group B demanded for rescue analgesia. At 12 hours of observation 4 patients from both groups demanded for rescue analgesia (table 7).

Table 1: Demographic profile of patients

\begin{tabular}{|l|c|c|c|}
\hline Demographic & Group A & Group B & P-value \\
\hline Age (Yrs) (Mean \pm SD) & $4.78 \pm 2.446$ & $5.240 \pm 2.521$ & $>0.05$ \\
\hline Weight (kg) (Mean \pm SD) & $14.76 \pm 4.35$ & $16.12 \pm 6.29$ & $>0.05$ \\
\hline Duration of Surgery (min.) & $44.88 \pm 13.14$ & $44.52 \pm 13.27$ & $>0.05$ \\
\hline
\end{tabular}


Table 2: Mean value of pulse rate \& respiratory rate in both groups

\begin{tabular}{|l|c|c|c|c|c|c|}
\hline & \multicolumn{2}{|c|}{ Pre-operative } & \multirow{2}{*}{ P-value } & \multicolumn{2}{|c|}{ Post-operative } & \multirow{2}{*}{ P-value } \\
\cline { 2 - 3 } \cline { 5 - 6 } & Group A & Group B & & Group A & Group B & \\
\hline Pulse rate (Beats/min.) & $103.2 \pm 5.03$ & $102.96 \pm 5.6$ & $>0.05$ & $113.92 \pm 7.31$ & $117.20 \pm 8.74$ & $>0.05$ \\
\hline Respiratory rate (bpm) & $18.20 \pm 1.71$ & $17.68 \pm 1.68$ & $>0.05$ & $20.76 \pm 1.81$ & $20.24 \pm 1.92$ & $>0.05$ \\
\hline
\end{tabular}

Table 3: Pain Score

\begin{tabular}{|c|c|c|c|c|c|c|c|}
\hline & \multirow[t]{2}{*}{ Groups } & \multicolumn{4}{|c|}{ Pain Score } & \multirow[t]{2}{*}{$\mathbf{X}^{2}$} & \multirow{2}{*}{ P-value } \\
\hline & & $\mathbf{0}$ & 1 & 2 & 3 & & \\
\hline \multirow[t]{2}{*}{1 hr. post-op. } & $\mathrm{A}$ & $21(84 \%)$ & $4(16 \%)$ & 0 & 0 & \multirow[t]{2}{*}{0.135} & \multirow[t]{2}{*}{$>0.05$} \\
\hline & $\mathrm{B}$ & $20(80 \%)$ & $5(20 \%)$ & 0 & 0 & & \\
\hline \multirow{2}{*}{4 hrs post-op. } & A & $23(92 \%)$ & $2(8 \%)$ & 0 & 0 & \multirow[t]{2}{*}{0.222} & \multirow[t]{2}{*}{$>0.05$} \\
\hline & B & $22(88 \%)$ & $3(12 \%)$ & 0 & 0 & & \\
\hline \multirow[t]{2}{*}{$6 \mathrm{hrs}$ post-op. } & A & $22(88 \%)$ & $3(12 \%)$ & 0 & 0 & \multirow[t]{2}{*}{0.166} & \multirow[t]{2}{*}{$>0.05$} \\
\hline & B & $21(84 \%)$ & $4(16 \%)$ & 0 & 0 & & \\
\hline \multirow[t]{2}{*}{12 hrs post-op. } & $\bar{A}$ & $20(80 \%)$ & $4(16 \%)$ & $1(4 \%)$ & 0 & \multirow[t]{2}{*}{0.136} & \multirow[t]{2}{*}{$>0.05$} \\
\hline & B & $19(76 \%)$ & $5(20 \%)$ & $1(4 \%)$ & 0 & & \\
\hline \multirow[t]{2}{*}{24 hrs post-op. } & A & $21(84 \%)$ & $3(12 \%)$ & $1(4 \%)$ & 0 & \multirow[t]{2}{*}{0.142} & \multirow[t]{2}{*}{$>0.05$} \\
\hline & B & $21(84 \%)$ & $4(16 \%)$ & 0 & 0 & & \\
\hline
\end{tabular}

Table 4: Sedation Score

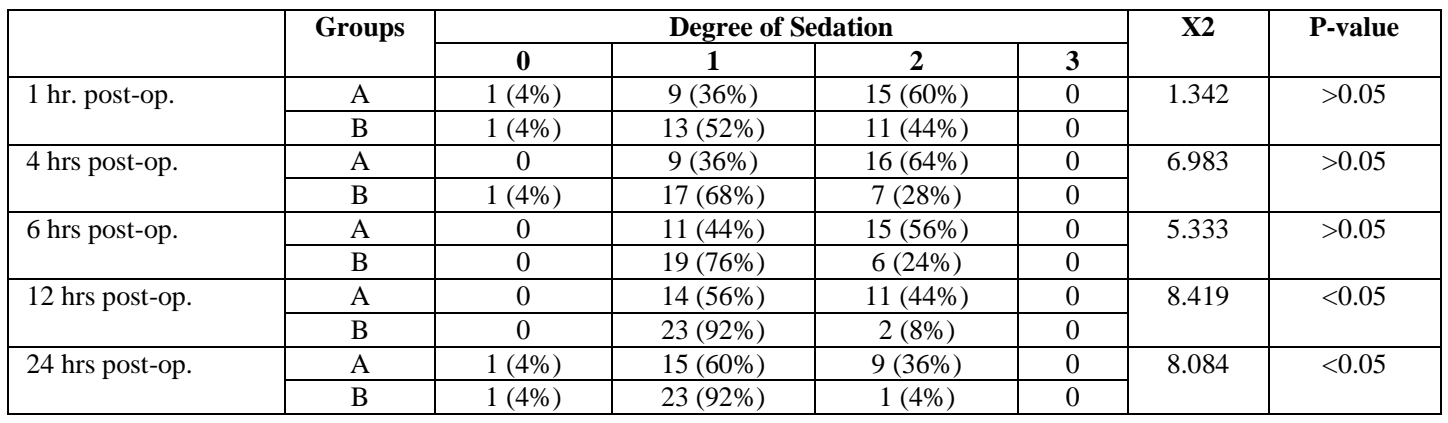

Table 5: Demeanour Score

\begin{tabular}{|c|c|c|c|c|c|c|}
\hline & \multirow[t]{2}{*}{ Groups } & \multicolumn{3}{|c|}{ Demeanour Scores } & \multirow[t]{2}{*}{$\mathbf{X}^{2}$} & \multirow[t]{2}{*}{ P-value } \\
\hline & & 1 & 2 & 3 & & \\
\hline \multirow[t]{2}{*}{$1 \mathrm{hr}$. post-op. } & A & $22(88 \%)$ & $2(8 \%)$ & $1(4 \%)$ & \multirow[t]{2}{*}{0.761} & \multirow[t]{2}{*}{$>0.05$} \\
\hline & $\mathrm{B}$ & $20(80 \%)$ & $4(16 \%)$ & $1(4 \%)$ & & \\
\hline \multirow{2}{*}{4 hrs post-op. } & A & $23(92 \%)$ & $2(8 \%)$ & 0 & \multirow[t]{2}{*}{1.022} & \multirow[t]{2}{*}{$>0.05$} \\
\hline & $\mathrm{B}$ & $22(88 \%)$ & $2(8 \%)$ & $1(4 \%)$ & & \\
\hline \multirow[t]{2}{*}{$6 \mathrm{hrs}$ post-op. } & $\mathrm{A}$ & $22(88 \%)$ & $3(12 \%)$ & 0 & \multirow[t]{2}{*}{0} & \multirow[t]{2}{*}{$>0.05$} \\
\hline & B & $22(88 \%)$ & $3(12 \%)$ & 0 & & \\
\hline \multirow[t]{2}{*}{12 hrs post-op. } & A & $23(92 \%)$ & $2(8 \%)$ & 0 & \multirow[t]{2}{*}{0.222} & \multirow[t]{2}{*}{$>0.05$} \\
\hline & $\mathrm{B}$ & $22(88 \%)$ & $3(12 \%)$ & 0 & & \\
\hline \multirow[t]{2}{*}{$24 \mathrm{hrs}$ post-op. } & A & $20(80 \%)$ & $4(16 \%)$ & $1(4 \%)$ & \multirow[t]{2}{*}{0} & \multirow[t]{2}{*}{$>0.05$} \\
\hline & $\mathrm{B}$ & $20(80 \%$ & $4(16 \%)$ & $1(4 \%)$ & & \\
\hline
\end{tabular}

Table 6: Degree of Motor Blockade

\begin{tabular}{|c|c|c|c|c|c|c|c|}
\hline & \multirow[t]{2}{*}{ Groups } & \multicolumn{4}{|c|}{ Bromage Scale } & \multirow[t]{2}{*}{$\mathbf{X}^{2}$} & \multirow[t]{2}{*}{ P-value } \\
\hline & & $\mathbf{0}$ & 1 & 2 & 3 & & \\
\hline & A & $12(48 \%)$ & $7(28 \%)$ & $5(20 \%)$ & $1(4 \%)$ & \multirow[t]{2}{*}{1.521} & \multirow[t]{2}{*}{$>0.05$} \\
\hline 1 hr. post-op. & $\mathrm{B}$ & $15(60 \%)$ & $6(24 \%)$ & $4(16 \%)$ & 0 & & \\
\hline \multirow{2}{*}{$4 \mathrm{hrs}$ post-op. } & A & $19(76 \%)$ & $5(20 \%)$ & $1(4 \%)$ & 0 & \multirow[t]{2}{*}{1.322} & \multirow[t]{2}{*}{$>0.05$} \\
\hline & B & $21(84 \%)$ & $4(16 \%)$ & 0 & 0 & & \\
\hline \multirow[t]{2}{*}{$6 \mathrm{hrs}$ post-op. } & A & $24(96 \%)$ & $1(4 \%)$ & 0 & 0 & \multirow[t]{2}{*}{1.020} & \multirow[t]{2}{*}{$>0.05$} \\
\hline & $\mathrm{B}$ & $25(100 \%)$ & 0 & 0 & 0 & & \\
\hline \multirow[t]{2}{*}{$12 \mathrm{hrs} \mathrm{post-op.}$} & A & $25(100 \%)$ & 0 & 0 & 0 & \multirow[t]{2}{*}{0} & \multirow[t]{2}{*}{$>0.05$} \\
\hline & B & $25(100 \%)$ & 0 & 0 & 0 & & \\
\hline \multirow[t]{2}{*}{24 hrs post-op. } & A & $25(100 \%)$ & 0 & 0 & 0 & \multirow[t]{2}{*}{0} & \multirow[t]{2}{*}{$>0.05$} \\
\hline & B & $25(100 \%)$ & 0 & 0 & 0 & & \\
\hline
\end{tabular}

Table 7: Demand of Rescue Analgesia

\begin{tabular}{|l|c|c|}
\hline Time (hrs.) & Group A & Group B \\
\hline $1 \mathrm{hrs}$ & 0 & 0 \\
\hline $4 \mathrm{hrs}$ & 0 & 0 \\
\hline $6 \mathrm{hrs}$ & $1(4 \%)$ & $2(8 \%)$ \\
\hline $12 \mathrm{hrs}$ & $4(20 \%)$ & $4(20 \%)$ \\
\hline $24 \mathrm{hrs}$ & $1(4 \%)$ & 0 \\
\hline
\end{tabular}




\section{Discussion}

Caudal block with local anaesthetic agent with or without adrenaline has already gained a wide popularity to provide intra-operative analgesia with or without supplementation of GA, particularly below umbilical surgery as well as to provide adequate post-operative analgesia depending upon the drug used for caudal block.

McGown RG $(1982)^{10}$ found that caudal anaesthesia in children is a technically simple procedure with low failure rate of $2.8 \%$ in his series. Brandao and Marlete (1969) ${ }^{11}$ also reported only $2.6 \%$ failure rate with caudal block. Thus, failure rate of $2 \%$ in the study coincided with the finding of above authors.

In our study, we induced the children either with intravenous pentothal or with gaseous inhalational agent prior to caudal block which allowed caudal block to be performed with more ease and intraoperative surgical conditions also remained satisfactory.

In the study the success rate of caudal administration was $98 \%$, remaining $2 \%$ of the patients not included in the study were probably due to some anatomical variations of sacral canal, thus further confirmed the findings of previous authors. There was also better haemodynamic stability in intra-operative period similar to the study of McGown RG in $1982 .^{10}$

We have opted injection bupivacaine as a local anaesthetic agent in concentration of $0.125 \%$ at a dose of $1 \mathrm{mg} / \mathrm{kg}$. Bupivacaine $0.125 \%$ provided equipotent analgesia and significantly less motor blockade than $0.25 \%$ bupivacaine for caudal block. Our findings are supported by the study of Wolf AR et al (1988) ${ }^{12}$.

We have also used burprenorphine caudal epidurally in a dose of $4 \mu \mathrm{g} / \mathrm{kg}$ body weight, that is in accordance with Girotra S et al (1990) ${ }^{7}$ and Anil Kumar TK et al (1994) ${ }^{13}$.

Rectal diclofenac carries the advantage of the possible avoidance of 'first pass' effect (De Boer AG et al in 1982) ${ }^{14}$ and thus reduces side effects seen with oral NSAIDs. The dose of rectal diclofenac $(2.5 \mathrm{mg} / \mathrm{kg})$ used in our study was based on the study conducted by Moores MA et al $(1990)^{15}$.

At all the specific time of observation, there was no statistical significant difference in pain scores upto 24 hours. After that we did not observe the patients. The mean duration of analgesia upto 24 hours have also been observed by Girotra $S$ et al $(1990)^{7} \&$ Anil Kumar TK et al (1994) ${ }^{13}$ who have used caudal buprenorphine. Gadiyar $\mathrm{V}$ et al $(1995)^{16} \&$ Moores MA et al (1990) ${ }^{15}$ have also reported mean duration of analgesia upto 24 hours when used rectal diclofenac $\mathrm{Na}$ without caudal bupivacaine, but in the intial post-operative period (upto 2-3 hrs), the children appreciated pain.

Sedation was seen more in group A as compared to group B at all the time of observation. It is not always possible to distinguish sedation from analgesia in children, and the greater sedative effect of buprenorphine might be mistaken for analgesia in children who fall sleep. Girotra $\mathrm{S}$ et al $(1990)^{7}$ also found significant incidences of sedation with caudal buprenorphine.

Majority of children in both groups were cheerful $\&$ calm. Girotra S et al (1990) ${ }^{7}$ found that all patients in caudal buprenorphine group were calm $\&$ cheerful at 8 hours after operation $(<0.01)$, where as in caudal bupivacaine group only $60 \%$ of patients were calm \& cheerful.

\section{Conclusion}

We concluded that caudal bupivacaine $0.125 \%$ in a dose of $1 \mathrm{ml} / \mathrm{kg}$ with rectal diclofenac $\mathrm{Na}$ suppository in a dose of $2.5 \mathrm{mg} / \mathrm{kg}$ just after induction of anaesthesia provides equivalent analgesia upto 24 hour in postoperative period with minimum side effects and lesser incidences of nausea and vomiting, sedation, time taken to void urine, in comparison to caudal bupivacaine in the same dose along with buprenorphine.

\section{References}

1. Campbell MF. Caudal Anaesthesia in children. Am J Urol.1933; 30:245-249. 
2. Fell D, Errington MC, Taylor $\mathrm{E}$ and Wanless JG. Paediatric postoperative analgesia. Anaesthesia 1988; 43:107-110.

3. Kehlet H. Surgical stress: The role of pain and analgesia. British Journal of Anaesthesia. 1989; 63: 189-95.

4. Dahl JB, Rosenberg J, Dirkes WE, Mogensent, Kehlet H. Prevention of postoperative pain by balanced analgesia. British Journal of Anaesthesia. 1990; 64: 518-20.

5. Stoelting RK. Opioid agonist and antagonist. In pharmacology and physiology in anaesthetic practice, $2^{\text {nd }}$ edition Philedelphia. J.B. Lippincott Company.1991; 95-101.

6. Lanz E, Simko G, Theiss D, Glocke MH. Epidural buprenorphine: a double blind study of post-operative analgesia and side effects. Anesth Analg. 1984; 63:593-98.

7. Girotra S, Kumar S. Post-operative analgesia in children who have genitorurinary surgery: a comparison between caudal buprenorphine and bupivacaine. Anaesthesia 1990; 45: 406-408.

8. Wolff J,Carl P and Crawford ME. Epidural buprenorphine for postoperative analgesia. A controlled comparison with epidural morphine. Anaesthesia 1986;41:76-79.

9. Gundersen RY, Andersen R, Narverid G. Postoperative pain relief with high dose epidural buprenorphine: a double blind study. Acta Anaesthesiologica Scandinavica 1986; 30:664-67.

10. Mc Gown RG. Caudal analgesia in children-five hundred cases for procedures below the diaphragm. Anaesthesia 1982;37:806-18.

11. Brandao, L de F, Marlete M. Anestesia caudal em pediatria. Revisa Brasil de Anestasia 1969; 19: 549.

12. Wolf AR, Valley RD, Fear DW, Roy WL, Lerman J. Bupivacaine for caudal analgesia in infants and children: The optimal effective concentration.

Anaesthesiology 1988; 69: 102-6.

13. Anil Kumar TK, Karpurkar SA, Shinde VS; Postoperative pain relief in children following caudal bupivacaine and buprenorphine- a comparative study. J Postgrad Med. 1994;40 (2):61-64.

14. De Boer AG, Moolenaar F, De Leede LGJ, Breimer D: Rectal drug administration: Clinical pharmacokinetic considerations Clinical Pharmacokinetics 1982; 7: 285311.

15. Moores MA, Wandless JG, Fell D. Paediatric post-operative analgesia. A comparison of rectal diclofenac with caudal bupivacaine after inguinal herniotomy. Anaesthesia 1990;45: 156-8.

16. Gadiyar V, Gallagher TM, Crean PM, Taylor RH. The effect of a combination of rectal diclofenac and caudal bupivacaine on post-operative analgesia in children. Anaesthesia 1995; 50:820-22. 